\title{
PENGARUH PRICE EARNING RATIO, DIVIDEND PAYOUT RATIO, VOLUME PERDAGANGAN, DAN NILAI TUKAR TERHADAP VOLATILITAS HARGA SAHAM PADA PERUSAHAAN KONSTRUKSI BANGUNAN YANG TERDAFTAR DI BEI
}

\author{
Diajeng Reztrianti ${ }^{1)}$ dan Budhi Suparningsih ${ }^{2)}$ \\ 1) Email: diajeng_r@unkris.ac.id \\ 2) Email: budhiunkris@gmail.com \\ Dosen Program Studi Manajemen FE UNKRIS \\ Alamat: Kampus UNKRIS, Jatiwaringin Jakarta Timur
}

\begin{abstract}
This study aims to determine the relationship between price earning ratio, dividend payout ratio, trading volume, and exchange rate on stock price volatility in building construction companies listed on the Stock Exchange, where this study uses a qualitative and quantitative design. Partially Dividend payout ratio has no significant effect on stock price volatility. Price earning ratio has a significant effect on stock price volatility. Trading volume has no significant effect on stock price volatility. The exchange rate has a significant influence on the volatility of stock prices. Simultaneously, price earning ratio, dividend payout ratio, trading volume and exchange rate have a significant influence on stock price volatility.
\end{abstract}

Keywords: Price earning ratio, dividen payout ratio, trading volume, exchange rate and Stock price volatility

\section{PENDAHULUAN}

Di Indonesia, investor dapat memilih banyak instrument investasi yang dapat digunakan untuk mendapatkan keuntungan, salah satunya adalah investasi saham di pasar modal. Hal ini karena dengan membeli produk keuangan di pasar modal, investor memiliki tujuan untuk mendapatkan keuntungan lebih besar daripada yang didapatkan dari tabungan atau deposito (Iswi dan Purnomo, 2010). Saham merupakan instrumen keuangan yang paling dominan diperdagangkan dalam pasar modal (Baskara, et al, (2020). Salah satu investasi yang dapat memberikan keuntungan yang cukup tinggi adalah saham Perusahaan konstruksi, karena perusahaan ini memiliki potensi besar untuk berkembang di Indonesia. Karena Indonesia adalah negara berkembang, permintaan terhadap konstruksi akan terus meningkat seiring dengan perkembangan pembangunan dinegara ini. Oleh karena itu, perusahaan konstruksi terus menghasilkan keuntungan positif setiap tahun, dan dapat menjadi salah satu alternatif pilihan dalam berinvestasi.

Sebuah perusahaan dapat mengalami return yang fluktuatif sewaktu-waktu karena berbagai macam faktor, baik mikro maupun makro. Untuk memastikan bahwa suatu investasi dapat memberikan keuntungan yang diharapkan investor, investor terlebih dahulu mencari informasi keuangan mengenai perusahaan melalui laporan keuangannya dan kemudian melakukan analisis. Selain tingkat pengembalian (return) saat berinvestasi, investor juga harus memperhatikan risiko yang akan dihadapinya. Khususnya volatilitas harga saham, Investor harus dapat memperkirakan keuntungan yang diperoleh dari investasinya dan konsekuensi tidak terduga dari investasi tersebut. Jika investor menginginkan return yang tinggi, maka harus bersedia mengambil risiko yang tinggi pula. 
Risiko adalah ketidakpastian yang akan muncul ketika mengambil suatu keputusan berdasarkan pertimbangan.

Dividen dan capital gain merupakan return saham yang diperhitungkan investor dalam kegiatan investasinya. Keputusan pendanaan perusahaan erat kaitannya dengan kebijakan dividen, dalam hal ini jumlah dividen yang diterima oleh investor semakin sedikit jika semakin besar laba yang ditahan oleh perusahaan (Berry, 2016). Oleh karena itu, rasio pembayaran dividen/dividend payout ratio (DPR) juga diperhatikan oleh investor dalam berinvestasi. Dividend Payout Ratio (DPR) merupakan perbandingan antara dividend per share (DPS) dan earning per share (EPS).

Kebijakan dividen akan mempengaruhi keputusan investor dalam berinvestasi. Pembayaran dividen yang tinggi merupakan sebuah sinyal yang menandakan bahwa perusahaan memiliki prospek yang bagus karena secara tidak langsung memberikan informasi kepada investor bahwa perusahaan dapat menciptakan laba yang tinggi sehingga dapat mengurangi risiko investasi. Hal ini dapat mempengaruhi harga saham perusahaan karena informasi tersebut yang diterima oleh investor akan mempengaruhi permintaan dan penawaran saham perusahaan.

Volatilitas di pasar saham terjadi juga karena pengaruh dari variabel makro ekonomi yang mempengaruhi harga saham (Sumathi, 2018). Oleh karena itu selain dari faktor mikro, faktor makro ekonomi juga perlu diperhatikan oleh investor, salah satunya adalah nilai tukar. Nilai tukar atau kurs (exchange rate) merupakan perbandingan nilai mata uang suatu negara terhadap nilai mata uang negara lain serta menunjukkan daya saing suatu perekonomian yang mana hal ini menunjukkan seberapa mata uang domestik dihargai oleh mata uang asing (Yugisvuri, 2016).

Menurut Hugida dan Sofian (2011), nilai indeks di BEI akan menurun ketika nilai tukar domestik mengalami depresiasi yang mana hal ini disebabkan return yang lebih tinggi di pasar uang dan investor tetap memegang sahamnya di pasar modal, sehingga penjualan saham tidak banyak terjadi, oleh karena itu hal ini menyebabkan kecenderungan volatilitas harga saham yang rendah. Dengan kata lain, nilai tukar mempunyai korelasi yang positif terhadap volatilitas harga saham. Menurut Prasad (2015), dolar AS dipandang sebagai mata uang yang paling aman karena Amerika Serikat memiliki perekonomian terbesar di dunia, politik yang terpercaya dan stabil, dan sistem pemerintah yang transparan dan saling mengawasi antar pemerintah.

Dalam kegiatan jual beli saham, investor menginginkan harga saham naik setelah dilakukan pembelian saham dan menginginkan harga saham turun setelah dilakukan penjualan saham. Harga saham dapat berfluktuasi dari waktu ke waktu karena keputusan investor untuk menjual atau membeli saham tersebut (Khasanah dan Fitri, 2019). Fluktuasi harga saham dapat dilihat dari volatilitas. Volatilitas adalah variasi perubahan harga aset selama periode tertentu (Sumathi, 2018). Dengan kata lain, semakin tinggi volatilitas harga saham, maka semakin tinggi juga ketidakpastian return yang akan didapatkan investor. Di pasar saham Indonesia sendiri, saat ini harga saham dari seluruh perusahaan masih belum stabil karena pada umumnya, pasar modal di pasar negara berkembang dianggap lebih berisiko dan volatile dibandingkan dengan pasar negara maju (Santioso \& Angesti, 2019 dan Zainudin, et al, 2017).

Bagi investor, volatilitas yang tinggi akan memberikan peluang untuk memperoleh keuntungan atau kerugian dalam jangka waktu yang pendek yang disebabkan oleh perubahan harga saham yang tidak menentu. Dalam hal ini, ketika harga saham sewaktuwaktu naik secara drastis maka investor akan mendapat keuntungan besar dari penjualan sahamnya, namun harga saham dapat pula turun secara drastis yang akan mengakibatkan kerugian pada investor. Beberapa investor cenderung menyukai saham yang memiliki 
volatilitas yang tinggi karena peluang memperoleh capital gain akan semakin besar walaupun disisi lain semakin besar pula resiko yang didapat. (Mawardi, 2018). Volatilitas yang tinggi disukai oleh investor yang berorientasi pada jangka pendek karena memberikan kesempatan kepada investor untuk memperoleh capital gain yang besar pada pergerakan harga saham yang tinggi sedangkan investor yang mempunyai orientasi jangka panjang menyukai volatilitas yang rendah karena risiko yang tidak terlalu besar pada pergerakan harga saham yang rendah (Chan \& Fong 2000 dalam Khasanah dan Fitri, 2019). Sehingga dapat disimpulkan bahwa pada volatilitas yang rendah, investor harus memegang saham dalam jangka panjang agar mendapatkan capital gain yang besar (Manurung, 2011). Dari hal tersebut menunjukkan kesempatan kepada investor untuk memanfaatkan fluktuasi harga dengan membeli saham saat harga turun dan menjual saat harga naik. Jadi, volatilitas perlu dipahami dengan baik oleh investor agar dapat memperoleh manfaat dari fluktuasi harga saham.

Menurut Jannah (2016) dalam Khasanah \& Fitri, 2019), terdapat faktor makro dan faktor mikro yang mempengaruhi volatilitas harga saham. Faktor makro merupakan faktor yang mempengaruhi ekonomi secara global serta memiliki dampak terhadap potensi keuntungan perusahaan seperti inflasi, nilai tukar rupiah, tingkat bunga, politik, tingkat produktivitas nasional, dan faktor lainnya yang memiliki dampak penting pada perusahaan, sedangkan faktor mikro merupakan faktor yang memiliki dampak langsung pada perusahaan itu sendiri dan dapat mempengaruhi perusahaan secara individual seperti produktivitas tenaga kerja, perubahan manajemen, ketersediaan bahan baku, dan faktor lain yang dapat mempengaruhi perusahaan. Diantara beberapa faktor tersebut, investor masih sulit menentukan faktor yang memiliki pengaruh dan prediksi paling dominan terhadap volatilitas harga saham. Oleh karena itu, volume perdagangan, dividend payout ratio, dan nilai tukar merupakan indikator-indikator yang mempengaruhi volatilitas harga saham dan perlu diperhatikan oleh investor.

Volume perdagangan sering dihubungkan dengan arus informasi yang masuk ke pasar, sehingga volume perdagangan adalah indikator yang kuat untuk memprediksi pasar karena harga saham berubah ketika informasi baru masuk ke (Mahajan dan Singh, 2009). Menurut Cha \& Fong (2000) dalam Priana \& Murliartha 2017), hubungan volume perdagangan dan volatilitas harga saham terbentuk karena adanya arus informasi asimetris yang diterima investor yang disebabkan oleh perbedaan karakter dan tipe investor dalam mengintepretasikan suatu informasi yang tersedia.

Pada umumnya, investor melihat volume perdagangan untuk menentukan tren harga di pasar. Hal ini karena perubahan volume perdagangan merupakan penyebab yang paling umum dalam meningkatnya volatilitas harga saham (Sabri, 2008). Tanda pasar semakin bagus ketika volume perdagangan menunjukkan tingkat yang tinggi pada suatu bursa (Indriastuti dan Nafiah, 2017).

\section{LANDASAN TEORI}

\section{Volatilitas Harga Saham}

Menurut Kotze (2005), volatilitas adalah variasi, dispersi, atau deviasi dari rata-rata pengembalian suatu aset yang mana secara sederhananya merupakan tingkat pergerakan harga dalam suatu saham, kontrak berjangka atau pasar lainnya. Dengan kata lain, volatilitas harga saham adalah kenaikan atau penurunan harga saham di bursa efek (Anastassia dan Firnanti, 2014). Volatilitas harga saham digunakan untuk mendefinisikan risiko saham biasa, dimana semakin besar volatilitas saham biasa, semakin besar pula risikonya (Zainudin dan 
Mahdzan, 2018).

Ada 5 jenis volatilitas di pasar keuangan, yaitu (Schwert dan W. Smith, Jr. 1992 dalam Hugida dan Sofian 2011): 1) Future Volatility; Apa yang hendak diketahui oleh trader (para pemain dalam pasar keuangan) merupakan future volatility. 2) Historical Volatility; Masa lalu perlu dipelajari untuk dapat mengetahui masa depan. Agar dapat memprediksi volatilitas di masa depan, teori pricing digunakan berdasarkan data masa lampau. 3) Forecast Volatility; Sama seperti beberapa layanan yang mencoba memprediksi arah masa depan dari harga kontrak. 4) Implied Volatility; adalah volatilitas yang harus diikutsertakan dalam model teoritis pricing agar nilai teoritis yang dihasilkan identik dengan harga option di pasar. 5) Seasonal volatility; Volatilitas jenis ini bergantung pada masa-masa tertentu, dengan kata lain suatu musim dapat mempengaruhi naik turunnya volatilitas.

\begin{tabular}{cccc}
\multicolumn{4}{c}{ Tabel 1: Volatilitas Harga Saham Periode 2010-2019 } \\
\hline $\begin{array}{c}\text { Tahun \& Kode } \\
\text { Perusahaan }\end{array}$ & ADHI & WIKA & PTPP \\
\hline 2010 & 0,0439 & 0,0426 & 0,0362 \\
2011 & 0,0358 & 0,0364 & 0,0420 \\
2012 & 0,0385 & 0,0364 & 0,0400 \\
2013 & 0,0500 & 0,0469 & 0,0529 \\
2014 & 0,0310 & 0,0276 & 0,0294 \\
2015 & 0,0374 & 0,0297 & 0,0268 \\
2016 & 0,0281 & 0,0286 & 0,0248 \\
2017 & 0,0267 & 0,0241 & 0,0280 \\
2018 & 0,0292 & 0,0329 & 0,0352 \\
2019 & 0,0269 & 0,0333 & 0,0354 \\
\hline
\end{tabular}

Sumber: Data diolah, 2021

Berdasarkan tabel 1, volatilitas harga saham masing-masing perusahaan konstruksi bangunan dan lainnya selama 10 tahun, WIKA memiliki volatilitas harga saham terendah di tahun 2017 dan PTPP memiliki volatilitas harga saham tertinggi di tahun 2013.

\section{Price Earning Ratio (PER)}

Price earning ratio merupakan ukuran yang paling banyak digunakan oleh investor untuk menganalisis apakah investasi yang dilakukan menguntungkan atau merugikan. Price earning ratio bermanfaat untuk melihat bagaimana pasar menghargai kinerja saham suatu perusahaan terhadap kinerja perusahaan yang tercermin dalam laba per sahamnya.

Menurut Sugiyanto (2008), price earning ratio adalah: rasio yang diperoleh dari harga pasar saham biasa dibagi dengan laba perusahaan. Maka semakin tinggi rasio akan mengindikasikan bahwa kinerja perusahaan semakin membaik, sebaliknya jika price earning ratio terlalu tinggi juga dapat mengindikasikan bahwa harga saham yang ditawarkan sudah tinggi atau tidak rasional.

Menurut Bringham dan Hoiston (2010), price earning ratio adalah "harga saham terhadap laba per saham menunjukkan jumlah yang rela dibayarkan oleh investor untuk setiap dolar laba yang dilaporkan". 
Tabel 2: Price Earning Ratio Periode 2010-2019

\begin{tabular}{cccc}
\hline $\begin{array}{c}\text { Tahun \& Kode } \\
\text { Perusahaan }\end{array}$ & ADHI & WIKA & PTPP \\
\hline 2010 & 7,1604 & 13,2659 & 18,1043 \\
2011 & 4,7483 & 9,3234 & 9,2196 \\
2012 & 12,7632 & 17,5807 & 12,3265 \\
2013 & 5,6941 & 15,7604 & 12,6730 \\
2014 & 16,4037 & 34,0149 & 30,8905 \\
2015 & 10,5419 & 23,6650 & 24,0725 \\
2016 & 23,6364 & 14,5490 & 18,4951 \\
2017 & 13,0000 & 11,5585 & 11,2821 \\
2018 & 8,7569 & 8,5742 & 7,4587 \\
2019 & 6,3172 & 7,8119 & 10,5667 \\
\hline
\end{tabular}

Sumber: Data diolah, 2021

Berdasarkan tabel 2, price earning ratio masing-masing perusahaan konstruksi bangunan dan lainnya selama 10 tahun, ADHI memiliki price earning ratio terendah di tahun 2011dan PTPP memiliki price earning ratio tertinggi ditahun 2014.

\section{Dividend Payout Ratio (DPR)}

Menurut Priana dan Murliartha (2017), dividend payout ratio adalah rasio yang mengukur perbandingan antara dividend per share dan earning per share. Dividend payout ratio menunjukkan proporsi laba per saham yang dibagikan kepada pemegang saham ekuitas sebagai dividen (Sarngadharan dan Kumar, 2011). Dengan kata lain, dividend payout ratio merupakan kebijakan dividen yang pada dasarnya menentukan berapa porsi laba yang akan diberikan kepada pemegang sahamnya dalam persentase.

Menurut Fitri, et al (2016), faktor-faktor yang dapat mempengaruhi dividend payout ratio yaitu: 1) Return on asset; Pengaruh profitabilitas terhadap pembayaran dividen karena dividen merupakan bagian dari laba bersih yang diperoleh perusahaan. Oleh karena itu, dividen akan dibagikan jika perusahaan memperoleh keuntungan. 2) Debt to equity ratio; adalah rasio yang mencerminkan kemampuan perusahaan dalam memenuhi semua kewajibannya yang ada, ditunjukkan dengan porsi modal sendiri yang digunakan untuk membayar hutang. 3) Pertumbuhan Aset; Aset digunakan untuk kegiatan operasional perusahaan, perusahaan dengan tingkat pertumbuhan dan peluang investasi yang tinggi akan membutuhkan dana internal yang besar untuk membiayai investasi tersebut, sehingga perusahaan cenderung membayar dividen yang rendah atau bahkan tidak dibayarkan. 4) Dividend payout ratio Setahun Sebelumnya; Perusahaan berusaha untuk mempertahankan atau bahkan meningkatkan rasio pembayaran dividen dari level sebelumnya.

Tabel 3: Dividend Payout Ratio Periode 2010-2019

\begin{tabular}{cccc}
\hline $\begin{array}{c}\text { Tahun \& Kode } \\
\text { Perusahaan }\end{array}$ & ADHI & WIKA & PTPP \\
\hline 2010 & 0,2224 & 0,1954 & 0,2288 \\
2011 & 0,2648 & 0,2611 & 0,2770 \\
2012 & 0,2199 & 0,2086 & 0,2210 \\
2013 & 0,0886 & 0,2236 & 0,2097 \\
2014 & 0,3187 & 0,5153 & 0,2252
\end{tabular}




\begin{tabular}{llll}
2015 & 0,1504 & 0,3591 & 0,1365 \\
2016 & 0,2980 & 0,1162 & 0,1411 \\
2017 & 0,1821 & 0,2525 & 0,4232 \\
2018 & 0,1599 & 0,1389 & 0,1937 \\
2019 & 0,1945 & 0,1515 & 0,3230 \\
\hline
\end{tabular}

\section{Sumber: Data diolah, 2021}

Berdasarkan tabel 3, dividend payout ratio masing-masing perusahaan konstruksi bangunan dan lainnya selama 10 tahun, WIKA memiliki dividend payout ratio terendah di tahun 2016 dan PTPP memiliki dividend payout ratio tertinggi di tahun 2017.

\section{Volume Perdagangan}

Investor yang rasional akan memperhitungkan tingkat keuntungan yang diharapkan dan risiko yang dihadapi dalam keputusan investasinya. Oleh karena itu, investor membutuhkan informasi dalam melakukan analisis terhadap investasi sahamnya.

Menurut Dani (2014), faktor-faktor yang mempengaruhi volume perdagangan adalah sebagai berikut: 1) Likuiditas; diartikan sebagai kemudahan untuk membeli atau menjual saham. 2) Volume breakout; Breakout disebut adalah situasi di mana harga menembus di atas level resistance dan mengarah lebih tinggi dari level resistance atau support alih-alih mengarah lebih rendah dari level support. 3) Manipulasi di pasar; Trader untuk mendapatkan keuntungan yang lebih besar terkadang melakukan pembelian atau penjualan artifisial dari saham untuk meningkatkan atau menurunkan volume saham tersebut. 4) Pengembalian dan portofolio sebelumnya; Investor mendasarkan keputusan investasinya pada portofolio yang mereka miliki dan juga pengalaman masa lalu. 5) Laporan berita dan media; Berita/peristiwa atau laporan tertentu yang dirilis oleh media berdampak besar terhadap sentimen investor.

Tabel 4: Volume Perdagangan Periode 2010-2019

\begin{tabular}{cccc}
\hline $\begin{array}{c}\text { Tahun \& Kode } \\
\text { Perusahaan }\end{array}$ & ADHI & WIKA & PTPP \\
\hline 2010 & 13.299 .832 & 27.660 .722 & 14.985 .891 \\
2011 & 6.802 .973 & 7.484 .415 & 9.136 .151 \\
2012 & 9.632 .347 & 13.298 .540 & 13.828 .725 \\
2013 & 23.569 .887 & 28.595 .268 & 32.236 .135 \\
2014 & 31.650 .326 & 29.798 .763 & 17.421 .101 \\
2015 & 26.389 .652 & 15.016 .280 & 10.464 .566 \\
2016 & 22.976 .519 & 16.932 .233 & 8.749 .923 \\
2017 & 16.208 .398 & 17.207 .172 & 17.001 .153 \\
2018 & 9.450 .796 & 21.690 .248 & 14.792 .634 \\
2019 & 8.009 .424 & 20.305 .429 & 21.560 .017 \\
\hline
\end{tabular}

Sumber: Data diolah, 2021

Berdasarkan tabel 4, volume perdagangan masing-masing perusahaan konstruksi bangunan dan lainnya selama 10 tahun, WIKA memiliki volume perdagangan terendah di tahun 2011 dan PTPP memiliki volume perdagangan tertinggi di tahun 2013.

\section{Nilai Tukar}

This work is licensed under a Creative Commons Attribution-NonCommercial-ShareAlike 4.0 International License. Ciptaan disebarluaskan di bawah Lisensi Creative Commons Atribusi-BerbagiSerupa 4.0 Internasional. 
Nilai tukar atau kurs memiliki pengaruh yang luas dan penting terhadap aspek perekonomian negara serta mempunyai peran vital dalam tingkat perdagangan suatu negara pada perekonomian ke arah yang lebih terbuka seperti saat ini yang mana terdapat perdagangan internasional antar negara-negara di dunia. Oleh karena itu dalam kegiatan ekspor dan impor antarnegara, terdapat perbedaan nilai tukar mata uang (kurs) yang disebabkan oleh perbedaan mata uang yang digunakan oleh negara bersangkutan. Besarnya permintaan dan penawaran mata uang pada prinsipnya menentukan perbedaan nilai tukar mata uang sebuah negara. (Pangestuti, 2020).

Nilai tukar mata uang asing ini dapat menyebabkan perubahan nilai investasi yang mana hal ini merupakan risiko dalam investasi. Fluktuasi nilai tukar mata uang dengan nilai mata uang lainnya berkaitan dengan risiko ini (Zulfikar, 2016). Menurut Pangestuti (2020), terdapat beberapa faktor yang mempengaruhi nilai tukar suatu negara, yaitu: 1) Tingkat inflasi; Perdagangan internasional menjadi dasar yang penting dalam pasar valas (valuta asing), sehingga keseimbangan pergerakan kurs valuta asing dipengaruhi oleh harga dalam negeri yang relatif terhadap harga luar negeri. Jika suatu negara yang memiliki konsistensi tingkat inflasi yang rendah, maka negara tersebut akan memperlihatkan nilai mata uang yang meningkat sejalan dengan meningkatnya daya beli relatif dibanding mata uang lainnya. 2) Perbedaan suku bunga pada berbagai negara; Para kreditur lebih tertarik menanamkan modalnya pada negara yang mempunyai suku bunga yang lebih tinggi karena memberikan imbal hasil yang lebih tinggi terhadap negara lain. Meningkatnya arus modal internasional dari modal asing ini menyebabkan nilai mata uang suatu negara meningkat. 3) Aktifitas neraca pembayaran; Dengan meningkatnya pemintaan dari debitur asing, neraca pembayaran yang aktif akan meningkatkan mata uang nasional. Sebaliknya, penurunan nilai tukar mata uang nasional disebabkan oleh neraca pembayaran yang pasif karena debitur dalam negeri menjual semuanya menggunakan mata uang asing untuk membayar kewajiban eksternal mereka. 4) ingkat pendapatan relatif; Melemahkan kurs mata uang asing dapat disebabkan oleh laju pertumbuhan pendapatan dalam negeri, sehingga permintaan valuta asing meningkat relatif dibandingkan dengan supply yang tersedia karena pendapatan riil dalam negeri. 5) Kontrol pemerintah; Kebijakan pemerintah dapat mempengaruhi nilai tukar seperti usaha untuk menghindari hambatan pada nilai tukar valuta asing dan perdagangan luar negeri, serta menjual dan membeli mata uang untuk mengintervensi di pasar. 6) Ekspektasi; Ekspektasi nilai tukar di masa yang akan datang dapat mempengaruhi nilai tukar valas karena pasar valas juga seperti pasar keuangan lainnya yang dapat bereaksi cepat terhadap berita mengenai dampak ke masa depan. 7) Interaksi antar faktor; Antara faktorfaktor mengenai perdagangan dan keuangan kadang saling berinteraksi. Sebagai contoh, kenaikan tingkat GNP dapat memunculkan ekspektasi meningkatnya suku bunga sehingga valuta domestik juga meningkat karena arus modal masuk meningkat yang dapat menutupi keluarnya valuta karena impor.

Nilai tukar (kurs) dapat dibedakan menjadi dua, yaitu (Mankiw, 2006): 1) Kurs nominal (nominal exchange rate), yaitu nilai tukar yang digunakan pada saat seseorang menukar suatu mata uang dengan mata uang negara lain atau dengan kata lain kurs jenis ini menunjukkan harga relatif dari mata uang dua negara. 2) Kurs riil (real exchange rate), yaitu nilai tukar yang digunakan seseorang ketika menukar barang atau jasa dari suatu negara dengan barang atau jasa dari negara lain, atau dengan kata lain kurs ini menunjukkan tingkat seseorang memperdagangkan barang atau jasa dari negara lain.

Menurut Kewal (2012), ada 4 jenis kurs dalam transaksi jual beli valuta asing, yaitu: 1) Selling rate (kurs jual), yaitu kurs untuk penjualan valas tertentu pada saat tertentu yang ditetapkan oleh suatu bank. 2) Middle rate (kurs tengah), yaitu kurs yang ditetapkan oleh bank sentral yang berada di antara kurs jual dan kurs beli valuta asing terhadap mata uang 
domestik pada saat tertentu. 3) Buying rate (kurs beli), yaitu kurs untuk pembelian valas asing tertentu yang ditetapkan oleh bank pada saat tertentu. 4) Flat rate (kurs flat), yaitu kurs yang berlaku dalam transaksi jual beli traveler chaque dan bank notes dimana dalam kurs ini telah diperhitungkan promosi dan biaya lain-lain.

Nilai tukar dapat diartikan sebagai harga mata uang asing dalam satuan mata uang domestik. Pada penelitian ini, variabel nilai tukar yang digunakan adalah nilai mata uang Indonesia (Rupiah) terhadap nilai mata uang Amerika Serikat (dolar AS). Nilai tukar diperoleh dari nilai kurs tengah rupiah terhadap dolar AS.

\begin{tabular}{cc} 
Tabel 5: Nilai Tukar Periode 2010-2019 \\
\hline Tahun & Nilai Tukar Rupiah \\
\hline 2010 & 8.991 \\
2011 & 9.068 \\
2012 & 9.670 \\
2013 & 12.189 \\
2014 & 12.440 \\
2015 & 13.795 \\
2016 & 13.436 \\
2017 & 13.548 \\
2018 & 14.481 \\
2019 & 13.901 \\
\hline
\end{tabular}

\section{Sumber: Data diolah, 2021}

Berdasarkan tabel 5, bahwa nilai tukar rupiah terhadap dolar AS mengalami fluktuasi. Dalam penelitian ini, nilai rupiah berada pada posisi terkuat dalam pada awal periode penelitian yaitu tahun 2010. Secara keseluruhan, nilai rupiah bergerak meningkat yang artinya nilai rupiah mengalami pelemahan terhadap dolar AS (depresiasi) selama periode 2010-2019. Pelemahan nilai tukar yang paling signifikan terjadi pada tahun 2013 sebesar Rp 12.189,-. Hal ini terjadi karena faktor global maupun domestik. Dari faktor global, nilai tukar rupiah mengalami depresiasi disebabkan adanya perbaikan ekonomi Amerika Serikat, penutupan (shutdown) Pemerintah Amerika Serikat, serta rencana tapering off yang dilakukan the Fed, yaitu Bank Sentral Amerika Serikat. Dari faktor domestik, nilai tukar rupiah mengalami depresiasi karena defisitnya transaksi berjalan yang diakibatkan oleh tingginya impor bahan bakar minyak (BBM) dan minyak mentah serta tingginya subsidi bahan bakar minyak (BBM).

\section{METODE PENELITIAN}

Penelitian ini dilakukan pada perusahaan konstruksi yang terdaftar di Bursa Efek Indonesia (BEI) dengan periode input data tahun 2010-2019. Data tersebut dapat diakses melalui website www.idx.co.id, www.bi.go.id, www.bps.go.id, www.finance.yahoo.com, dan www.sahamok.com. Penelitian ini dilaksanakan pada bulan Desember 2020 hingga selesai.

Populasi yang digunakan dalam penelitan ini adalah perusahaan Konstruksi yang terdaftar di Bursa Efek Indonesia periode 2010-2019 sebanyak sepuluh perusahaan. Sedangkan sampel yang diambil hanya 3 perusahaan konstruksi saja. Metode analisis menggunakan regresi linier sederhana dan berganda. Sebelum dianalisis, terlebih dahulu dilakukan uji asumsi klasik. 


\section{HASIL PENELITIAN DAN PEMBAHASAN}

\section{Hasil Penelitian}

\section{Asumsi Klasik}

\section{Uji Normalitas}

Uji normalitas bertujuan untuk mengetahui apakah model regresi pada variabel independen, variabel dependen, maupun keduanya berdistribusi normal atau tidak. Dalam penelitian ini, uji normalitas yang digunakan adalah uji Kolmogorov-Smirnov.

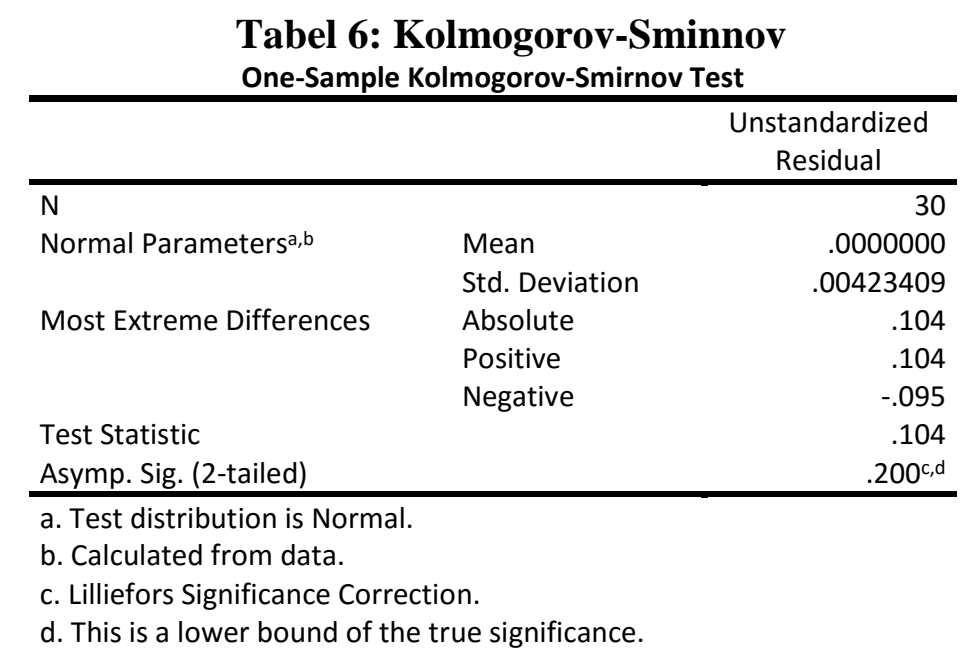

Berdasarkan tabel 6, nilai dapat dilihat nilai sig menghasilkan nilai 0,200 yang artinya nilai sig > derajat alpha 0,05 . Oleh karena itu, model regresi dengan variabel terikat volatilitas harga saham berdistribusi secara normal berdasarkan uji Kolmogorov-Smirnov tersebut.

\section{Uji Multikolinieritas}

Tujuan dilakukannya uji multikolinieritas adalah untuk mengetahui model regresi apakah ada atau tidaknya korelasi antara variabel bebas atau variabel independen. Jika tidak terdapat korelasi diantara variabel-variabel bebasnya, maka data tersebut dapat dikatakan baik. Jika ada korelasi, maka data tersebut dapat dikatakan memiliki masalah multikolinearitas. Untuk menguji multikolinearitas, nilai Tolerance dan VIF perlu diperhatikan. Terdapat suatu pedoman persamaan regresi tidak terjadi masalah multikolinieritas yaitu sebagai berikut: 1) Mempunyai nilai Tolerance lebih dari 0,1. 2) Mempunyai nilai Variance Inflation Factor (VIF) kurang dari 10. 
Tabel 7: Uji Multikolinieritas

\begin{tabular}{|c|c|c|c|}
\hline \multicolumn{4}{|c|}{ Coefficiensts $^{\mathrm{a}}$} \\
\hline \multirow[b]{2}{*}{ Model } & & \multicolumn{2}{|c|}{ Collinearity Statistics } \\
\hline & & Tolerance & VIF \\
\hline \multirow[t]{5}{*}{1} & (Constant) & & \\
\hline & PER & .781 & 1.280 \\
\hline & DPR & .787 & 1.271 \\
\hline & VOLUME & .885 & 1.130 \\
\hline & NT & .920 & 1.087 \\
\hline
\end{tabular}

a. Dependent Variable: Volatilitas

Sumber: Data diolah, 2021

Berdasarkan tabel 7, semua nilai tolerance pada volume perdagangan, price earning proce, dividend payout ratio, volume perdagangan dan nilai tukar kurang dari 0,1 dan nilai VIF kurang dari 10. Maka dapat disimpulkan bahwa model regresi dengan volatilitas harga saham tidak terjadi masalah multikolinieritas sehingga data tersebut dapat digunakan pada penelitian ini.

\section{Uji Autokorelasi}

Uji Autokorelasi dilakukan untuk menguji apakah dalam model regresi terdapat korelasi antara kesalahan pengganggu pada periode $\mathrm{t}$ dengan kesalahan pada periode sebelumnya (t-1). Pada penelitian ini, analisis uji autokorelasi dilakukan dengan uji Durbin Watson, yaitu dengan membandingkan nilai Durbin Watson (DW) antara DW pada hasil uji dengan DW tabel. Data menunjukkan tidak terdapat gangguan autokorelasi jika nilai DW pada hasil uji berada diantara dU dan (4-dU).

Tabel 8: Uji Autokorelasi

\begin{tabular}{lrrrrr}
\hline Model & R & R Square & $\begin{array}{c}\text { Adjusted R } \\
\text { Square }\end{array}$ & $\begin{array}{l}\text { Std. Error of } \\
\text { the Estimate }\end{array}$ & $\begin{array}{l}\text { Durbin- } \\
\text { Watson }\end{array}$ \\
\hline 1 & $.827^{\mathrm{a}}$ & .684 & .634 & .0045603 & 1.862 \\
\hline
\end{tabular}

a. Predictors: (Constant), NT, DPR, VOLUME, PER

b. Dependent Variable: Volatilitas

Berdasarkan tabel 8, uji Durbin-Watson menunjukkan nilai 1,862. Nilai tersebut kemudian dibandingkan dengan nilai tabel dengan menggunakan tingkat signifikansi 5\%, jumlah variabel bebas atau " $\mathrm{k}$ " $=4$ dan jumlah sampel atau " $\mathrm{N} "=30$. Hasil tabel yaitu dU $=$ 1,7386 dan 4-dU $=2,2614$. Hal ini menunjukkan bahwa nilai DW pada hasil uji berada diantara nilai dU dan 4-dU (dU < DW < 4-dU atau 1,7486 < 1,862 <2,2614). Sehingga dapat ditarik kesimpulan bahwa persamaan model regresi tidak terjadi masalah autokorelasi. 


\section{Analisis Regresi Linier Sederhana}

Tabel 9: Pengaruh Price Earning Ratio terhadap Volatilitas Harga Saham

\begin{tabular}{lcccccc}
\hline \multicolumn{1}{c}{ Variabel } & $\mathbf{6}$ & \multicolumn{6}{c}{ Parameter } \\
\hline & $\mathbf{R}$ & $\begin{array}{c}\text { R } \\
\text { Square }\end{array}$ & Konstanta & $\begin{array}{c}\text { Koefisien } \\
\text { Regresi }\end{array}$ & Sig & $\boldsymbol{\alpha}$ \\
\hline PER & 0,371 & 0,138 & 0,040 & 0,000 & 0,043 & 0.05 \\
\hline
\end{tabular}

Pengujian Signifikan

t hitung $=-2,116$

Keterangan: Variabel Volatilitas Harga Saham

Sumber: Data diolah 2021

Berdasarkan tabel 9, nilai $\mathrm{R}$ square sebesar 0,138 menunjukkan kontribusi price earning ratio kepada volatilitas harga saham sebesar 13,8, sedangkan sisanya $86,2 \%$ dipengaruhi oleh variabel lain diluar penelitian ini.

$$
\text { Persamaan Regresi }=\mathrm{Y}=0,040+0,000 \mathrm{X} 1
$$

Nilai koefisien regresi price earning ratio adalah 0,000 . Hal ini berarti jika terdapat kenaikan $1 \%$ price earning ratio, maka akan diikuti oleh kenaikan volatilitas harga saham sebesar $0,000 \%$. Uji t dilakukan untuk mengetahui tingkat signifikansi atau ada tidaknya pengaruh price earning ratio terhadap volatilitas harga saham secara individual. Price earning ratio dapat dikatakan memiliki pengaruh signifikan apabila nilai probabilitas pada hasil uji lebih kecil dari taraf signifikansi yang digunakan, yaitu 0,05. Nilai signifikansi price earning ratio adalah 0,043 dimana nilai ini lebih kecil daripada taraf signifikansi $(0,05)$. Hal ini memiliki arti bahwa H0 ditolak sehingga H1 diterima. Dengan kata lain, price earning ratio memiliki pengaruh signifikan terhadap volatilitas harga saham.

Tabel 10: Pengaruh Dividend Payout terhadap Volatilitas Harga Saham

\begin{tabular}{lcccccc}
\hline Variabel & \multicolumn{6}{c}{ Parameter } \\
\hline & $\mathbf{R}$ & $\begin{array}{c}\text { R } \\
\text { Square }\end{array}$ & Konstanta & $\begin{array}{c}\text { Koefisien } \\
\text { Regresi }\end{array}$ & Sig & $\boldsymbol{\alpha}$ \\
\hline DPR & 0,206 & 0,043 & 0,038 & $-0,017$ & 0,274 & 0.05 \\
\hline
\end{tabular}

Pengujian Signifikan

t hitung $=-1,116$

Keterangan: Variabel Volatilitas Harga Saham

Sumber: Data diolah 2021

Berdasarkan tabel 10, nilai $\mathrm{R}$ square sebesar 0,043 menunjukkan kontribusi dividend payout ratio kepada volatilitas harga saham sebesar $4,3 \%$, sedangkan sisanya $95,7 \%$ dipengaruhi oleh variabel lain diluar penelitian ini.

$$
\text { Persamaan Regresi }=\mathrm{Y}=0,038-0,017 \mathrm{X} 2
$$

Nilai koefisien regresi dividend payout ratio adalah -0,017. Hal ini berarti jika terdapat kenaikan $1 \%$ dividend payout ratio, maka akan diikuti oleh penurunan volatilitas harga 
saham sebesar $0,017 \%$. Uji t dilakukan untuk mengetahui tingkat signifikansi atau ada tidaknya pengaruh dividend payout ratio terhadap volatilitas harga saham secara individual. Dividend payout ratio dapat dikatakan memiliki pengaruh signifikan apabila nilai probabilitas pada hasil uji lebih kecil dari taraf signifikansi yang digunakan, yaitu 0,05. Nilai signifikansi dividend payout ratio adalah 0,274 dimana nilai ini lebih besar daripada taraf signifikansi $(0,05)$. Hal ini memiliki arti bahwa $\mathrm{H} 0$ diterima sehingga $\mathrm{H} 2$ ditolak. Dengan kata lain, Dividend payout ratio tidak memiliki pengaruh signifikan terhadap volatilitas harga saham.

Tabel 11: Pengaruh Volume Perdagangan terhadap Volatilitas Harga Saham

\begin{tabular}{lcccccc}
\hline \multicolumn{1}{c}{ Variabel } & $\mathbf{6}$ & Parameter \\
\hline & $\mathbf{R}$ & $\begin{array}{c}\mathbf{R} \\
\text { Square }\end{array}$ & Konstanta & $\begin{array}{c}\text { Koefisien } \\
\text { Regresi }\end{array}$ & Sig & $\boldsymbol{\alpha}$ \\
\hline VOLUME & 0,312 & 0,097 & 0,029 & 3,088 & 0,093 & 0.05 \\
\hline Pengujian Signifikan & & & & & \\
\hline t hitung = 1,738 & \multicolumn{7}{l}{} \\
\hline
\end{tabular}

Keterangan: Variabel Volatilitas Harga Saham

Sumber: Data diolah 2021

Berdasarkan tabel 11, nilai $\mathrm{R}$ square sebesar 0,097 menunjukkan kontribusi volume perdagangan kepada volatilitas harga saham sebesar 9,7\%, sedangkan sisanya 90,3\% dipengaruhi oleh variabel lain diluar penelitian ini.

$$
\text { Persamaan Regresi }=\mathrm{Y}=0,029+3,088 \mathrm{X} 3
$$

Nilai koefisien regresi volume perdagangan adalah 3,088. Hal ini berarti jika terdapat kenaikan 1 satuan volume perdagangan, maka akan diikuti oleh kenaikan volatilitas harga saham sebesar 3,088 satuan. Uji t dilakukan untuk mengetahui tingkat signifikansi atau ada tidaknya pengaruh volume perdagangan terhadap volatilitas harga saham secara individual. Volume perdagangan dapat dikatakan memiliki pengaruh signifikan apabila nilai probabilitas pada hasil uji lebih kecil dari taraf signifikansi yang digunakan, yaitu 0,05. Nilai signifikansi volume perdagangan adalah 0,093 dimana nilai ini lebih besar daripada taraf signifikansi $(0,05)$. Hal ini memiliki arti bahwa H0 diterima sehingga H3 ditolak. Dengan kata lain, volume perdagangan tidak memiliki pengaruh signifikan terhadap volatilitas harga saham.

Tabel 12: Pengaruh Nilai Tukar terhadap Volatilitas Harga Saham

\begin{tabular}{lcccccc}
\hline \multicolumn{1}{c}{ Variabel } & \multicolumn{6}{c}{ Parameter } \\
& $\mathbf{R}$ & $\begin{array}{c}\text { R } \\
\text { Square }\end{array}$ & Konstanta & $\begin{array}{c}\text { Koefisien } \\
\text { Regresi }\end{array}$ & Sig & $\boldsymbol{\alpha}$ \\
\hline Nilai_Tukar & 0,517 & 0,268 & 0,058 & $-1,904$ & 0,003 & 0.05 \\
\hline Pengujian Signifikan & & & & & \\
\hline t hitung = -3,200 & & & & & \\
\hline
\end{tabular}

Keterangan: Variabel Volatilitas Harga Saham

Sumber: Data diolah 2021

Berdasarkan Tabel 12, nilai $\mathrm{R}$ square sebesar 0,268 menunjukkan kontribusi nilai tukar kepada volatilitas harga saham sebesar 26,8, sedangkan sisanya 73,2\% dipengaruhi oleh variabel lain diluar penelitian ini. 
Nilai koefisien regresi nilai tukar adalah -1,904. Hal ini berarti jika terdapat kenaikan satu satuan nilai tukar, maka akan diikuti oleh penurunan volatilitas harga saham sebesar 1,904 satuan. Uji t dilakukan untuk mengetahui tingkat signifikansi atau ada tidaknya pengaruh nilai tukar terhadap volatilitas harga saham secara individual. Nilai tukar dapat dikatakan memiliki pengaruh signifikan apabila nilai probabilitas pada hasil uji lebih kecil dari taraf signifikansi yang digunakan, yaitu 0,05 . Nilai signifikansi nilai tukar adalah 0,003 dimana nilai ini lebih kecil daripada taraf signifikansi $(0,05)$. Hal ini memiliki arti bahwa $\mathrm{H} 0$ ditolak sehingga H4 diterima. Dengan kata lain, nilai tukar memiliki pengaruh signifikan terhadap volatilitas harga saham.

\section{Analisis Regresi Linier Berganda}

Tabel 13: Pengaruh PER, DPR, Volume Perdagangan, dan Nilai Tukar terhadap Volatilitas Harga

\begin{tabular}{lcccccc}
\hline \multirow{2}{*}{ Variabel } & \multicolumn{5}{c}{ Parameter } \\
\cline { 2 - 7 } & Mult. R & $\begin{array}{c}\text { R } \\
\text { Square }\end{array}$ & Konstanta & $\begin{array}{c}\text { Koefisien } \\
\text { Regresi }\end{array}$ & Sig. & $\boldsymbol{\alpha}$ \\
\hline PER & & & & 0,000 & 0,010 \\
DPR & 0,827 & 0,683 & 0,062 & $-0,019$ & 0,082 & 0.05 \\
VOLUME & & & & 5,736 & 0,000 & 0.00 \\
NT & & & & $-2,311$ & 0,000 & \\
\hline
\end{tabular}

Pengujian Signifikan

F hitung $=13,536$

Keterangan: Variabel Volatilitas_Harga Saham

Sumber: data diolah 2021

Berdasarkan Tabel 13, nilai $\mathrm{F}$ hitung sebesar 13,537 atau dengan menggunakan probability signifikan yaitu sebesar 0,000 lebih kecil dari tingkat kepercayaan 0,05, Hal ini memiliki arti bahwa H0 ditolak sehingga H5 diterima. Dengan kata lain, price earning ratio, dividend payout ratio, volume perdagangan dan nilai tukar memiliki pengaruh secara simultan signifikan terhadap volatilitas harga saham. Nilai Koefisien Determinasi $\left(\mathrm{R}^{2}\right)$ sebesar 0.684 , artinya price earning ratio, dividend payout ratio, volume perdagangan dan nilai tukar memberikan kontribusi sebesar $68,4 \%$ kepada volatilitas harga saham, sedangkan sisanya sebesar $31,6 \%$ disumbangkan faktor lain yang tidak dibahas dalam penelitian ini.

$$
\text { Persamaan Regresi } Y=0,062+0,000\left(X_{1}\right)-0,019\left(X_{2}\right)+5,736\left(X_{3}\right)-2,311\left(X_{4}\right)
$$

Price earning ratio, dividend payout ratio, volume perdagangan dan nilai tukar berpengaruh signifikan terhadap volatilitas harga saham, pada tingkat nyata 99\%. Koefisien price earning price sebesar 0,000 artinya jika ada peningkatan price earning ratio $1 \%$, maka volatilitas harga saham akan meningkat sebesar $0,000 \%$ atau sebaliknya dengan asumsi dividend payout ratio, volume perdagangan dan nilai tukar tidak berubah. Koefisien dividend payout ratio sebesar $-0,019$, artinya jika ada peningkatan dividend payout ratio $1 \%$, maka volatilitas harga saham akan menurun sebesar $0,019 \%$ atau sebaliknya, dengan asumsi price earning ratio, volume perdagangan dan nilai tukar tidak berubah. Koefisien volume perdagangan sebesar 5,736, artinya jika ada peningkatan volume perdagangan satu satuan 
maka volatilitas harga saham akan meningkat sebesar 5,736 satuan atau sebaliknya, dengan asumsi price earning ratio, dividend payout ratio dan nilai tukar tidak berubah. Koefisien nilai tukar sebesar -2,311, artinya jika ada peningkatan nilai tukar satu satuan maka volatilitas harga saham akan menurun sebesar 2,311 satuan atau sebaliknya, dengan asumsi price earning ratio, dividend payout ratio dan volume perdagangan tidak berubah.

\section{Pembahasan}

\section{Pengaruh Price Earning Ratio terhadap Volatilitas Harga Saham Perusahaan Konstruksi Bangunan yang Terdaftar di Bursa Efek Indonesia}

Berdasarkan hasil penelitian menunjukkan bahwa price earning ratio mendukung peningkatan volatilitas harga saham. Hal ini dikarenakan bahwa Price earning ratio merupakan ukuran yang paling banyak digunakan oleh investor untuk menganalisis apakah investasi yang dilakukan menguntungkan atau merugikan, sedangkan volatilitas adalah variasi atau deviasi dari pengembalian suatu asset, hal ini mencerminkan bahwa harga saham industri konstruksi dan bangunan ini di pasar tidak terlalu berfluktuasi sehingga variasi deviasi pengembalian return saham tersebut lebih stabil dan dapat mengurangi resiko kerugian atas investasinya di saham tersebut. Hasil penelitian ini sama dengan hasil penelitian yang dilakukan oleh Pomartia, et al, (2018). Dalam penelitian tersebut menyatakan bahwa Price Earning Ratio berpengaruh negatif dan signifikan terhadap volatilitas harga saham. Tinggi rendahnya pendapatan laba perusahaan menyebabkan price earning ratio perusahaan berbeda-beda sehingga mempengaruhi minat investor untuk berinvestasi atau tidak yang akan mempengaruhi volatilitas harga saham.

\section{Pengaruh Dividend Payout Ratio terhadap Volatilitas Harga Saham Perusahaan Konstruksi Bangunan yang Terdaftar di Bursa Efek Indonesia}

Berdasarkan hasil penelitian menunjukkan bahwa dividend payout ratio tidak mendukung peningkatan volatilitas harga saham. Seperti kita ketahui bahwa dividend payout ratio adalah rasio yang mengukur perbandingan antara dividend per share dan earning per share. Dividend payout ratio menunjukkan proporsi laba per saham yang dibagikan kepada pemegang saham ekuitas sebagai dividen, dengan demikian penelitian ini menunjukkan bahwa deviden yang dibagikan tidak sesuai dengan harapan para investor, yang disebabkan karena peluang investasi yang tinggi pada industri konstruksi membutuhkan dana internal yang cukup besar untuk membiayai investasi tersebut, sehingga perusahaan cenderung membayar dividen yang rendah atau bahkan tidak dibayarkan. Hasil penelitian ini sama dengan hasil penelitian yang dilakukan oleh Phan dan Tran (2019) yang menyatakan bahwa dividend payout ratio tidak berpengaruh terhadap volatilitas harga saham.

\section{Pengaruh Volume Perdagangan terhadap Volatilitas Harga Saham Perusahaan Konstruksi Bangunan yang Terdaftar di Bursa Efek Indonesia}

Berdasarkan hasil penelitian menunjukkan bahwa volume perdagangan tidak mendukung peningkatan volatilitas harga saham. Hal ini dikarenakan bahwa faktor yang menggerakkan harga saham bukan hanya permintaan dan penawaran saja, situasi dan tren ekonomi makro yang terjadi pada periode tertentu juga mendasari pergerakan saham. Hal ini berarti, investor tidak memperhatikan volume perdagangan saham ketika berinvestasi di pasar modal. Hasil penelitian ini sama dengan hasil penelitian yang dilakukan oleh Phan dan Tran (2019), yang menyatakan bahwa volume perdagangan tidak berpengaruh terhadap volatilitas harga saham. 


\section{Pengaruh Nilai Tukar terhadap Volatilitas Harga Saham Perusahaan Konstruksi Bangunan yang Terdaftar di Bursa Efek Indonesia.}

Berdasarkan hasil penelitian menunjukkan bahwa nilai tukar mendukung peningkatan volatilitas harga saham. Hal ini dikarenakan bahwa nilai tukar merupakan indikator yang sangat penting dalam makro ekonomi sebuah negara sehingga investor perlu memperhatikan perubahan nilai tukar pada saat melakukan investasi di pasar modal maupun di pasar uang. Hasil penelitian ini sama dengan hasil penelitian yang dilakukan oleh Selpiana dan Badjra (2018) yang menyatakan bahwa nilai tukar berpengaruh terhadap volatilitas harga saham.

Pengaruh Price Earnig Ratio, Dividend Payout Ratio, Volume Perdagangan, dan Nilai Tukar terhadap Volatilitas Harga Saham Perusahaan Konstruksi Bangunan yang Terdaftar di Bursa Efek Indonesia

Berdasarkan hasil penelitian menunjukkan bahwa price earnig ratio, dividend payout ratio, volume perdagangan dan nilai tukar mendukung peningkatan Volatilitas Harga Saham. Hal ini dapat dijelaskan bahwa volatilitas harga saham perusahaan konstruksi selain dipengaruhi oleh fundamental keuangan juga dipengaruhi oleh fundamental makro, oleh karena hal tersebut maka para investor harus mempunyai literasi keuangan sebelum melakukan investasi di pasar modal. Hasil penelitian ini sama dengan hasil penelitan yang dilakukan oleh Mobarak dan Mahfud, (2017). Hasil penelitian tersebut menyatakan variabel independen yaitu kebijakan dividen, book value per share, earning volatility, leverage, price earning ratio, dan volume perdagangan secara bersama-sama berpengaruh terhadap variabel dependen yaitu volatilitas harga saham perusahaan Go Public Non keuangan yang listing di Bursa Efek Indonesia periode 2012-2015. Secara parsial dividend payout ratio dan book value per share mempunyai pengaruh positif dan tidak signifikan terhadap volatilitas harga saham. Earning volatility dan price earning ratio mempunyai pengaruh negatif dan signifikan terhadap volatilitas harga saham. Sedangkan leverage dan volume perdagangan berpengaruh positif dan signifikan terhadap volatilitas harga saham.

\section{KESIMPULAN DAN SARAN}

\section{Kesimpulan}

Berdasarkan hasil analisis penelitian yang telah dilakukan mengenai pengaruh price earning ratio, dividend payout ratio, volume perdagangan dan nilai tukar terhadap volatilitas harga saham perusahaan kontruksi bangunan yang terdaftar di BEI tahun 2010-2019, kesimpulan yang dapat diperoleh yaitu sebagai berikut: 1) Price earning ratio mendorong peningkatan volatilitas harga saham perusahaan kontruksi bangunan. 2) Dividend payout ratio tidak mendorong peningkatan volatilitas harga saham perusahaan kontruksi bangunan. 3) Volume perdagangan mendorong peningkatan volatilitas harga saham perusahaan kontruksi bangunan. 4) Nilai tukar mendorong peningkatan volatilitas harga saham perusahaan kontruksi bangunan.

\section{Saran}

Karena adanya keterbatasan pada penelitian ini, maka peneliti memberikan rekomendasi sebagai berikut: 1) Bagi peneliti, dengan topik penelitian yang sejenis, dapat disarankan agar melakukan kajian lebih lanjut dengan melibatkan variabel dari fundamental mikro dan fundamental makro lainnya seperti firm size, ROA, ROE, tingkat inflasi, tingkat SBI, dan faktor mikro dan makro lainnya. 2) Bagi pembaca dengan minat investasi saham, disarankan untuk memperhatikan volume perdagangan dalam kegiatan investasinya agar 
memperhatikan risiko dari volatilitas harga saham, dimana semakin tinggi volume perdagangan, semakin tinggi pula volatilitas harga saham. 3) Bagi perusahaan kontruksi bangunan, disarankan untuk lebih memperhatikan tingkat volume perdagangan sahamnya sehingga dapat menarik investor untuk berinvestasi pada perusahaan.

\section{DAFTAR PUSTAKA}

Anastassia, A., dan Firnanti, F. 2014. Faktor-faktor yang Mempengaruhi Volatilitas Harga Saham pada Perusahaan Publik Nonkeuangan. Jurnal Bisnis dan Akuntansi, 16 (2), 95-102.

Baskara, G. P., Suyanto, S., dan Rahayu, S. R. 2020. Pengaruh Volume Perdagangan dan Simple Moving Average Terhadap Harga Saham. Jurnal Akuntansi AKTIVA, 1 (1), 116.

Berry, M. 2016. Technology Focus: Artificial Lift. Journal of Petroleum Technology, 68 (07), 67-67.

Brigham, E.F., dan Houston, J.F. 2010. Dasar-dasar Manajemen Keuangan. Jakarta: Salemba.

Dani, V. 2014. Stock Market and Factors Affecting Trading Volume. International Journal, 2 (3).

Fitri, R. R., Hosen, M. N., dan Muhari, S. 2016. Analysis of Factors That Impact Dividend Payout Ratio on Listed Companies at Jakarta Islamic Index. International Journal of Academic Research in Accounting, Finance and Management Sciences, 6(2), 87-97.

Hugida, L., dan Sofian, S. 2011. Analisis Faktor-Faktor Yang Mempengaruhi Volatilitas Harga Saham (Studi Pada Perusahaan Yang Terdaftar Dalam Indeks LQ45 Periode 2006-2009) (Doctoral dissertation, Universitas Diponegoro).

Indriastuti, A., dan Nafiah, Z. 2017. Pengaruh Volume Perdagangan, Kurs dan Risiko Pasar Terhadap Return Saham. Jurnal Stie Semarang (Edisi Elektronik), 9(1), 57-66.

Iswi, H., dan Serfianto, R. 2010. Buku Pintar Hukum Bisnis Pasar Modal (Strategi Tepat Investasi Saham, Obligasi, Waran, Right, Opsi, Reksadana \& Produk Pasar Modal Syariah. Visimedia, Jagakarsa.

Kewal, S. S. 2012. Pengaruh Inflasi, Suku Bunga, Kurs, dan Pertumbuhan PDB Terhadap Indeks Harga Saham Gabungan. Jurnal Economia, 8 (1), 53-64.

Khasanah, N., dan Fitri, L. W. 2019. Pengaruh Dividend Policy, Trading Volume, dan Order Imbalance Terhadap Volatilitas Harga Saham (Doctoral dissertation, IAIN Surakarta).

Kotze, A. A. 2005. Stock Price Volatility: A Primer Financial Chaos Theory.

Mahajan, S., danSingh, B. 2009. The Empirical Investigation of Relationship Between Return, Volume and Volatility Dynamics in Indian Stock Market. Eurasian Journal of Business and Economics, 2(4), 113-137.

Mankiw, N. Gregory.2006. Pengantar Ekonomi Makro. Edisi Ketiga. Salemba Empat Jakarta.

Manurung, A. H. 2011. Kaya dari Bermain Opsi di Bursa Saham. Jakarta: Penerbit Buku Kompas.

Mawardi, W. 2018. Determinants of the Stock Price Volatility in the Indonesian Manufacturing Sector. International Research Journal of Business Studies, 11(3), 179193.

Mobarak, R., dan Mahfud, M. K. 2017. Analisis Pengaruh Kebijakan Dividen, BVPS, Earning Volatility, Leverage, Per, dan Volume Perdagangan Terhadap Volatilitas 
Harga Saham (Studi Empiris Pada Perusahaan Go Public Non Keuangan yang Listing Di Bursa Efek Indonesia Tahun 2012-2015). Diponegoro Journal of Management, 6 (2), 209-221.

Pangestuti, D. C. 2020. Manajemen Keuangan Internasional. Deepublish.

Phan, T. K. H., dan Tran, N. H. 2019. Dividend Policy and Stock Price Volatility in an Emerging Market: Does Ownership Structure Matter? Cogent Economics \& Finance, 7 (1), 1637051.

Pomartia, T. Z., Mulyadi, J. M. V., dan Rachbini, W. 2018. Analisis Volatilitas Harga Saham Dengan ROA dan ROE Sebagai Variabel Kontrol (Studi Pada Perusahaan Yang Terdaftar Dalam Indeks LQ45). Ekobisman: Jurnal Ekonomi Bisnis dan Manajemen, 3 (2), 138-147.

Prasad, E. S. 2015. The Dollar Trap. Princeton University Press.

Priana, I. W. K., dan Murliartha, K. 2017. Pengaruh Volume Perdagangan Saham, Leverage, dan Dividend Payout Ratio pada Volatilitas Harga Saham. E- Jurnal Akuntansi, [online] 20 (1), hal. 1-29.

Sabri, N. R. 2008. The Impact of Trading Volume on Stock Price Volatility in The Arab Economy. Journal of derivatives \& Hedge funds, 14(3), 285-298.

Santioso, L., dan Angesti, Y. G. 2019. Faktor-Faktor Yang Mempengaruhi Volatilitas Harga Saham Perusahaan Manufaktur. Jurnal Ekonomi, 24(1), 46-64.

Sarngadharan, M. 2011. Financial Analysis for Management Decisions. PHI Learning Pvt. Ltd.

Schwert, G. W., \& Smith Jr, C. W. 1992. Empirical Research in Capital Markets.

Selpiana, K. R., dan Badjra, I. B. 2018. Pengaruh Kebijakan Dividen, Nilai Tukar, Leverage, Dan Firm Size Terhadap Volatilitas Harga Saham. E-Jurnal Manajemen Unud, 7 (3), 1682-1712.

Sugiyanto. 2008. Pasar Modal, Cetakan Kedua. Alfabeta, Bandung.

Sumathi, D. 2018. Stock Price Volatility in National Stock Exchange of India. International Journal of Research in Economics and Social Sciences (IJRESS), 8(12).

Yugisvuri, 2016. Analisis Pengaruh Nilai Tukar, Inflasi, Dividend Yield, dan Dividend Payout Ratio Terhadap Volatilitas Harga Saham Perusahaan yang Terdaftar di Jakarta Islamic Index Periode 2010-2014.

Zainudin, R., Mahdzan, N. S., dan Yet, C. H. 2018. Dividend Policy and Stock Price Volatility of Industrial Products Firms in Malaysia. International Journal of Emerging Markets.

Zulfikar, Z., dan Si, M. (2016). Pengantar Pasar Modal Dengan Pendekatan Statistika. CV Budi Utama. 